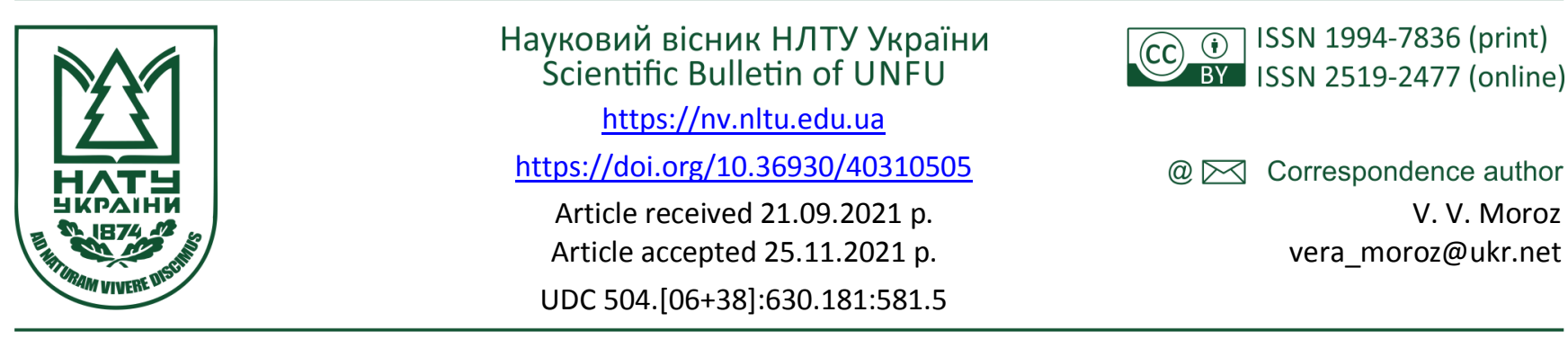

В. В. Мороз ${ }^{1}$ Н. М. Стасюк², Т. П. Федонюк ${ }^{1}$

${ }^{1}$ Поліський національний університет, м. Житомир, Украӥна ${ }^{2}$ Інститут агроекології і природокористування НААН, м. Київ, Украӥна

\title{
ОСОБЛИВОСТІ РОСТУ, РОЗВИТКУ ТА КЛІМАТОСТАБІЛІЗАЦІЙНЕ ЗНАЧЕННЯ ЯЛИНОВИХ НАСАДЖЕНЬ УКРАЇНСЬКИХ КАРПАТ
}

\begin{abstract}
3 огляду на зобов'язання, які стоять перед Україною відповідно до Паризької угоди, є нагальна потреба в обліку обсягу поглинання вуглецю й удосконаленні методичних підходів до кліматостабілізаційної здатності деревних рослин. Для цього здійснено низку наукових досліджень, які охоплювали визначення особливостей росту та приросту за діаметром ялинових лісових насаджень в Українських Карпатах за лісогосподарськими округами: Прикарпатському, Гірськокарпатському і Закарпатських рівнин і передгір'я. Під час аналізу запропоновано математичні залежності розвитку ялини європейської (Picea abies (L.) H. Karst.) за висотою, діаметром та віком дерева. За емпіричними рівняннями встановлено, що ялина європейська краще росте у Гірськокарпатському лісогосподарському окрузі. У зазначеному окрузі висота ялини вища на 7 \%, ніж у Передкарпатському округу і на 16 \%, ніж у Закарпатському окрузі. Також встановлено, що у Гірськокарпатському лісогосподарському окрузі діаметр ялини є більшим за Передкарпатський на $2 \%$, а за Закарпатський на $1 \%$. За допомогою пакету аналізу даних Microsoft Excel побудовано кореляційні матриці, за допомогою яких встановлено тісні взаємозв'язки між такими показниками, як вік, висота, діаметр і фітомаса окремих фракцій дерева. Здійснено регресійний і дисперсний аналізи та отримано математичні залежності, за допомогою яких встановлено біологічну продуктивність Picea abies (L.) H. Karst. в Українських Карпатах. За методиками IPCC (Intergovernmental Panelon Climate Change, 2015), П. I. Лакиди (2002), G. Matthews (1993) і І. Я. Лієпи (1980) визначено вуглецепоглинальну та киснетвірну здатність ялини європейської у віці 70 років на площі 1 га за умов Українських Карпат. Визначено, що на площі 1 га ялинові насадження найбільше поглинають вуглець - 93,9 т, і виробляють кисень - 276,8 т в окрузі Закарпатських рівнин і передгір'я. У Гірськокарпатському лісогосподарському окpyзі Picea abies (L.) H. Karst поглинає 85,9 т вуглецю і виробляє 253,1 т кисню, а в Прикарпатському - 67,1 і 197,7 т відповідно. Проаналізовано викиди діоксиду вуглецю в навколишне середовище в умовах Українських Карпат за період 20102020 pр. З'ясовано, що за десятирічний період середній показник викидів вуглекислого газу $\left(\mathrm{CO}_{2}\right)$ становив 18,6 млн т. Визначено, що ялинові насадження в повному обсязі знижують викиди діоксиду вуглецю в середовищі. Запропоновані математичні рівняння дадуть змогу здійснювати моніторинг обсягу поглинання вуглецю і продукування кисню Picea abies (L.) H. Karst. у різних лісорослинних округах Українських Карпат.
\end{abstract}

Ключові слова: вуглець; кисень; фітомаса; рівняння; вуглекислий газ.

\section{Вступ / Introduction}

Головним резервуаром біологічно зв'язаного вуглецю є ліси (містять до 500 млрд т), що становить $2 / 3$ його запасу в атмосфері. При утворенні 1 т абсолютно сухої ваги рослинної продукції зв'язується 1,5-1,8 т вуглекислого газу і вивільняється 1,1-1,3 т кисню. Площа 1 га середньо продуктивного лісонасадження (за запасом насадження) акумулює за рік 6-7 т вуглекислого газу i виділяє в атмосферу 5-6 т кисню. 3 усієї маси вуглецю, що міститься в рослинності, найбільша його частка зосереджена в лісових екосистемах - $92 \%$. У рослинах всіх інших екосистем акумульовано тільки близько $7 \%$ вуглецю, а в рослинних організмах океану - менше ніж
$1 \%[5]$.

Зрозуміло, що розширення площ під лісами, як і підвищення їх продуктивності, сприяло б якщо не нейтралізації, то сповільненню процесів нагромадження вуглецю в атмосфері, оскільки лісові насадження є головним наземним поглиначем вуглекислого газу. Збільшення площ насаджень i покращення їх біопродуктивності за допомогою раціонального ведення лісового господарства сприяло б покращенню клімату на планеті.

Враховуючи участь України в Паризький угоді і зобов'язання, які стоять перед Україною щодо покращення клімату і зменшення обсягів викиду вуглекислого газу $\left(\mathrm{CO}_{2}\right), \epsilon$ нагальна потреба у наукових дослідженнях 3

\section{Інформація про авторів:}

Мороз Віра Василівна, канд. с.-г. наук, доцент, кафедра біології та захисту лісу. Email: vera_moroz@ukr.net; https://orcid.org/0000-0002-1457-4641

Стасюк Наталія Михайлівна, наук. співробітник, відділ охорони ландшафтів, збереження біорізноманіття і природозаповідання. Email: wien@ukr.net; https://orcid.org/0000-0002-9184-4078

Федонюк Тетяна Павлівна, д-р с.-г. наук, професор, керівник навчально-наукового центру екології та охорони навколишнього середовища. Email: tanyavasiluk2015@gmail.com; https://orsid.org/0000-0002-6504-0893

Цитування за ДСту: Мороз В. В., Стасюк Н. М., Федонюк Т. П. Особливості росту, розвитку та кліматостабілізаційне значення ялинових насаджень Українських Карпат. Науковий вісник НЛтУ України. 2021, т. 31, № 5. С. 36-41.

Citation APA: Moroz, V. V., Stasyuk, N. M., \& Fedonyuk, T. P. (2021). Some peculiarities of growth, development and climate-stabilizing significance of spruce stands of the Ukrainian Carpathians. Scientific Bulletin of UNFU, 31(5), 36-41.

https://doi.org/10.36930/40310505 
вуглецепоглинальної та киснепродуктивної здатності лісових насаджень України. Тому ми розробили математичні залежності для визначення особливостей росту та розвитку ялинових насаджень у трьох лісогосподарських округах Українських Карпат, встановили їх кліматостабілізаційне значення (вуглецепоглинальне та киснепродукувальне), визначили частку зниження $\mathrm{CO}_{2}$ у навколишньому середовищі Карпат завдяки вуглецепоглинальній здатності ялинових лісів.

Об'єкт дослідження - кліматостабілізаційне значення Picea abies (L.) H. Karst. в умовах Українських Карпат.

Предмет дослідження - методи і засоби визначення вуглецепоглинальної та киснепродукувальної здатності ялинових насаджень залежно від їхньої висоти та діаметра.

Мета роботи - з'ясувати особливості розвитку ялини європейської за лісогосподарськими округами Українських Карпат та визначити кліматостабілізаційну здатність (вуглецепоглинальна, киснепродуктивна).

Для досягнення зазначеної мети визначено такі основні завдання дослідження:

- проаналізувати динаміку розвитку ялини європейської за діаметром та віком;

- проаналізувати динаміку росту ялини за віком;

- розробити рівняння пофракційної фітомаси ялини;

- розробити рівняння конверсійних коефіцієнтів;

- визначити вуглецепоглинальну та киснетвірну здатність ялинових насаджень за лісогосподарськими округами;

- встановити обсяги поглинання вуглецю ялиновими насадженнями в умовах Українських Карпат.

Наукова новизна отриманих результатів дослідження - вперше за лісогосподарськими округами запропоновано рівняння залежності розвитку ялини європейської (за віком, висотою та діаметром дерева). Запропоновано рівняння фітомаси в абсолютно сухому стані різних фракцій дерева (кора, деревина, крона), а також конверсійні коефіцієнти для встановлення об'єму фітофракцій ялини. Встановлено вуглецепоглинальну та киснепродукувальну здатність ялинових насаджень у різних лісогосподарських округах в умовах Українських Карпат.

Практична значущість результатів дослідження одержані математичні залежності наддадуть змогу прогнозувати розвиток ялини європейської за висотою, діаметром та віком в умовах Українських Карпат за лісогосподарськими округами, а також встановити їх вуглецепоглинальну та киснетвірну здатність, що сприяє стабільності клімату.

Аналіз останніх досліджень та публікацій. Кліматостабілізаційне значення деревних рослин визначають через моделювання їх біопродуктивної здатності з подальшим визначенням вуглецепоглинальної та киснепродукувальної здатності. Біопродуктивність кожної деревної породи залежить від кліматичних умов та місцезростання. Вітчизняні вчені, зокрема П. І. Лакида (2006, 2009, 2011), С. І. Миклуш (2011), М. А. Голуб (2003), В. І. Білоус (2009), В. П. Пастернак (2011), Р. Д. Василишин (2014) та ін., розробили методи оцінювання біологічної продуктивності лісових насаджень. Наукові дослідження цих учених ми доповнили дослідженнями Г. Г. Гриника, А. І. Задорожнього, В. М. Ловинської, С. А. Ситника, Н. Ю. Висоцької та ін. [1, 2, 9, $10,13,14,15,16]$ та дослідженнями іноземних науков- ців Л. М. Гитарського, А. В. Іванова та ін. [1, 3] й удосконалили методами математичного моделювання [4, 8].

Матеріали та методи дослідження. Для встановлення екологічної ролі ялинових насаджень дослідний матеріал збирали на державних підприємствах (ДП), що розташовані в лісогосподарських округах, в яких виконували дослідження:

- у Передкарпатському лісогосподарському окрузі: ДП "Коломийське лісове господарство", ДП "Івано-Франківське лісове господарство", ДП "Дрогобицьке лісове господарство", ДП "Старосамбірське лісомисливське господарство", ДП "Сторожинецьке лісове господарство", Спеціалізоване лісогосподарське агропромислове підприємство "Сторожинецький держспецлісгосп", "Глибоцький державна спеціалізоване лісогосподарське підприємство агропромислового комплексу", ДП "Чернівецьке лісове господарство", ДП "Вигодське лісове господарство", ДП "Кіцманський ліс агропромислового комплексу";

- у Гірськокарпатському лісогосподарському окрузі: ДП "Великоберезнянське лісове господарство", ДП "Верхньогірське лісове господарство", ДП "Турківське лісове господарство", ДП "Славське лісове господарство", ДП "Сколівське лісове господарство", ДП "Вижницьке державне спеціалізоване підприємство агропромислового комплексу", ДП "Боринське лісове господарство", ДП "Кутське лісове господарство";

- в лісогосподарському окрузі Закарпатських рівнин і передгір'я: ДП "Виноградівське лісове господарство", ДП "Довжанське лісомисливське господарство", ДП "Тячівське лісове господарство", ДП "Хустське лісове дослідне господарство", ДП "Брустурянське лісомисливське господарство", ДП "Іршавське лісове господарство", ДП "Моркянське лісомисливське господарство", ДП "Міжгірське лісове господарство".

Тимчасові пробні площі закладали в ялинових насадженнях згідно з СОУ 02.02-37-476:2006 "Пробні площі лісовпорядні. Метод закладання". За біометричними показниками (ріст, діаметр, вік) визначали розвиток ялинових насаджень Карпатського регіону за лісогосподарськими округами.

Першим кроком для встановлення вуглецепоглинальної та киснепродукувальної ролі є визначення біомаси дерева. Адже біомаса дерева відіграє істотну роль у процесі фотосинтезу дерева. Біомасу дерева визначали за формулою

$$
m=V \cdot \rho_{\text {bas }},
$$

де: $p_{b a s}$ - базисна щільність фракції фітомаси, кг $/ \mathrm{M}^{3} ; \mathrm{m}-$ маса зразка фракції фітомаси в абсолютно сухому стані, кг; $V$ - об'єм стовбура зразка залежно від діаметра та висоти, м ${ }^{3}$.

Базисну щільність фракцій фітомаси $\left(p_{b a s}\right)$ використовували за опублікованими даними таких авторів, як О. І. Полубоярінов, І. П. Лакида $[6,12]$. Об'єм кори, деревини визначали за нормативно-довідковими таблицями (Кашпор, Строчинський; 2013) [4]. Фітомасу крони ялини європейської (Picea abies (L.) H. Karst) встановлювали за "Нормативами оцінки компонентів надземної фітомаси деревостанів головних лісотвірних порід України" (Лакида та ін., 2013) [7].

Отримані дані були апроксимовані емпіричним рівнянням множинної статистичної алометрії, яке описує залежності компонентів фітомаси дерева від його морфометричних показників (висота, діаметр):

$$
y=a_{0} \cdot x_{1}^{a_{1}} \cdot x_{2}^{a_{2}}
$$

де: $a_{0}, a_{1}, a_{2}$ - константи, відомі в економетрії як похідна функції Кобба-Дугласа; $x_{1}, x_{2}$ - морфометричні по- 
казники дерева, у нашому випадку $x_{1}-$ діаметр, см; $x_{2}-$ висота, м.

Фітомасу насадження (т/га) визначали як фітомасу всіх дерев у насадженні на одиниці площі. Для швидкого визначення біопродуктивності деревостану розроблено конверсійні коефіцієнти за рівнянням [6]

$$
R_{V}=\frac{M_{f r}}{M}=a \cdot A^{b},
$$

де: $R_{V}-$ конверсійний коефіцієнт, т/м³ $; M_{f r}-$ фітомаса певної фракції деревостану, т/га; м - запас деревини у корі, м/га; $a, b$ - постійні коефіцієнти регресії; $A$ - вік насадження, роки.

Частка вуглецю у фітомасі в абсолютно сухому стані, за методикою IPCC (Intergovernmental Panelon Climate Change, 2015), становить 50 \% від фітомаси фракцій в абсолютно сухому стані. G. Matthews (1993) запропонував для хвої використовувати частку $45 \%$ [11]. Киснепродуктивність у лісонасадженнях оцінено за методикою І. Я. Лієпи [8].

\section{Результати дослідження та їх обговорення / Research results and their discussion}

Залежно від кліматичних і географічних умов зростання залежить ріст і діаметр деревних рослин. Беручи до уваги отримані показники під час подеревної таксації на тимчасових пробних площах, ми отримали математичні рівняння росту та розвитку (за діаметром) ялинових насаджень Українських Карпат за лісогосподарськими округами:

Передкарпатський лісогосподарський округ:

$$
\begin{aligned}
& h=16,1 \cdot \ln (A)-44,2, R^{2}=0,862, \\
& d=18,3 \cdot \ln (A)-49,9, R^{2}=0,771 ;
\end{aligned}
$$

Гірськокарпатський лісогосподарський округ:

$$
\begin{aligned}
& h=17,2 \cdot \ln (A)-46,7, R^{2}=0,846, \\
& d=20,1 \cdot \ln (A)-56,4, R^{2}=0,908 ;
\end{aligned}
$$

Лісогосподарський округ Закарпатських рівнин і передгір'я:

$$
\begin{aligned}
& h=13,3 \cdot \ln (A)-35,2, R^{2}=0,785, \\
& d=17,2 \cdot \ln (A)-46,2, R^{2}=0,854,
\end{aligned}
$$

де: $h$ - висота дерева, м; $d$ - діаметр дерева, см; $A$ - вік дерева, роки.

Високі коефіцієнти детермінації рівнянь (0,771$0,862)$ свідчать про достатню апроксимацію та можливість їх подальшого використання для прогнозування росту та розвитку ялини в умовах Українських Карпат за лісогосподарськими округами. За отриманими рівняннями побудовано графіки залежності (рис. 1).

Згідно з отриманими результатами аналізу (див. рис. 1) можна стверджувати, що ялина європейська краще росте у Гірськокарпатському лісогосподарському окрузі. Показник висоти в зазначеному окрузі $є$ вищий на 7 \% за показник Передкарпатського округу та на 16 \% за показник Закарпатського округу. За діаметром показник у Гірськокарпатському лісогосподарському окрузі $\epsilon$ більший на $2 \%$, ніж у Передкарпатському і на $1 \%$, ніж у Закарпатському окрузі рівнин і передгір'я.

Для встановлення кореляційних взаємозв'язків між таксаційними показниками та фітомасою різних фракцій ялинових насаджень, за допомогою пакету аналізу даних Microsoft Excel, побудовано кореляційні матриці для кожного лісогосподарського округу окремо (табл. 1).
Між показниками фітомаси та біометричними показниками (висота, діаметр, вік) у ялинових насадженнях існує кореляційний взаємозв'язок від 0,595 до 0,931. Для отримання степеневих рівнянь для ялинових насаджень прологарифмовано всі показники, та здійснено пошук залежностей між фітомасою деревини та біометричними показниками за допомогою регресійного аналізу. Результати розрахунків наведено у табл. 2 і 3 .
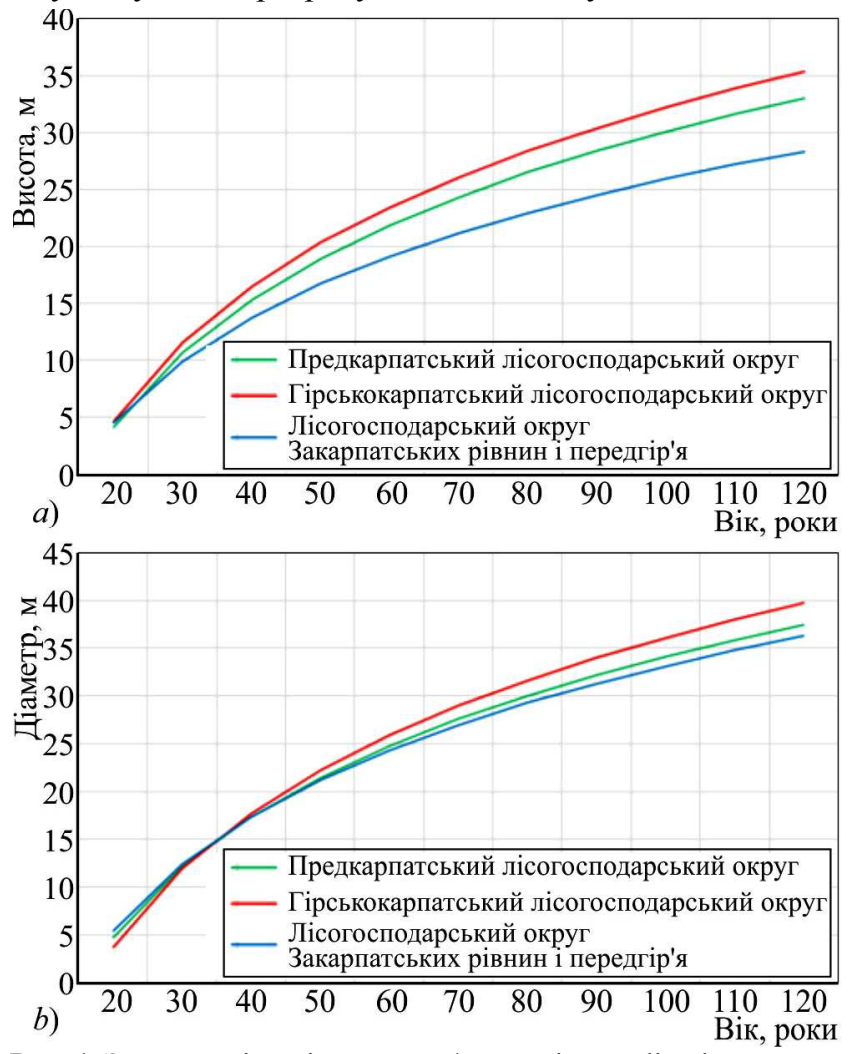

Рис. 1. Залежності за рівняннями / Improving quality due to:

a) середньої висоти та віку / average height and age;

b) середнього діаметра та віку / average diameter and age

Повертаємо до початкової функції показник $Y$ та отримуємо

$$
\ln 10(-1,8)=1,5 \times 10^{-2} .
$$

Згідно з функцією Кобба-Дугласа, степеневе рівняння буде мати такий вигляд:

$$
y=1,5 \cdot 10^{-2,0} \cdot x_{1}^{1,9} \cdot x_{2}^{0,9},
$$

де: $y$ - середня фітомаса деревини ялини, кг; $x_{1}-$ діаметр дерева, см; $x_{2}-$ висота дерева, м.

Отже, збільшення діаметра дерева на 1,9\% і висоти на $0,9 \%$ має безпосередній вплив на збільшення фітомаси дерева. Міра визначеності дорівнює 0,999, що свідчить про достатню апроксимацію отриманого степеневого рівняння $з$ вихідними показниками. Множинний $R$ є достатньо високим і дорівнює 0,999. Згідно 3 дисперсним аналізом, рівняння є значущим на $5 \%$-му рівні, тому що значущість $F$ є менша ніж 0,05 .

Отримане степеневе рівняння буде мати вигляд:

$$
y=4,9 \cdot 10^{-3,0} \cdot x_{1}^{1,6} \cdot x_{2}^{0,9},
$$

де: $y$ - середня фітомаса кори ялини, кг; $x_{1}$ - діаметр дерева, см; $x_{2}$ - висота дерева, м.

Коефіцієнт детермінації $R^{2} €$ достатньо високим 0,998, що вказує на вірогідність рівняння. Кореляційний зв'язок (множинний $R$ ) між показниками високий 0,999. Дисперсійний аналіз вказав, що рівняння є значущим на 5 \%-му рівні, значущцість $F \in$ менша ніж $0,05$. 
Табл. 1. Матриця парних коефіцієнтів кореляції Picea abies (L.) H. Karst. /

The matrix of paired correlation coefficients of Picea abies (L.) H. Karst.

\begin{tabular}{|c|c|c|c|c|c|c|}
\hline Показник & $\begin{array}{c}\text { Вік, } \\
\text { років }\end{array}$ & $\begin{array}{c}\text { Середня } \\
\text { висота, м } \\
\end{array}$ & $\begin{array}{c}\text { Середній } \\
\text { діаметр, см }\end{array}$ & $\begin{array}{l}\text { Середня фітома- } \\
\text { са деревини, кг }\end{array}$ & \begin{tabular}{|l|} 
Середня фіто- \\
маса кори, кг \\
\end{tabular} & $\begin{array}{l}\text { Середня фіто- } \\
\text { маса крони, кг }\end{array}$ \\
\hline \multicolumn{7}{|c|}{ Передкарпатського лісогосподарського округу } \\
\hline Вік, років & 1,00 & - & - & - & - & - \\
\hline Середня висота, м & 0,855 & 1,00 & - & - & - & - \\
\hline Середній діаметр, см & 0,817 & 0,822 & 1,00 & - & - & - \\
\hline Середня фітомаса деревини, кг & 0,876 & 0,857 & 0,971 & 1,00 & - & - \\
\hline Середня фітомаса кори, кг & 0,867 & 0,874 & 0,973 & 0,997 & 1,00 & - \\
\hline Середня фітомаса крони, кг & 0,824 & 0,795 & 0,989 & 0,985 & 0,982 & 1,00 \\
\hline \multicolumn{7}{|c|}{ Гірськокарпатського лісогосподарського округу } \\
\hline Вік, років & 1,00 & - & - & - & - & - \\
\hline Середня висота, м & 0,874 & 1,00 & - & - & - & - \\
\hline Середній діаметр, см & 0,806 & 0,980 & 1,00 & - & - & - \\
\hline Середня фітомаса деревини, кг & 0,695 & 0,613 & 0,463 & 1,00 & - & - \\
\hline Середня фітомаса кори, кг & 0,825 & 0,959 & 0,962 & 0,510 & 1,00 & - \\
\hline Середня фітомаса крони, кг & 0,804 & 0,858 & 0,867 & 0,699 & 0,767 & 1,00 \\
\hline \multicolumn{7}{|c|}{ Лісогосподарський округ Закарпатських рівнин і передгір'я } \\
\hline Вік, років & 1,00 & - & - & - & - & - \\
\hline Середня висота, м & 0,623 & 1,00 & - & - & - & - \\
\hline Середній діаметр, см & 0,873 & 0,840 & 1,00 & - & - & - \\
\hline Середня фітомаса деревини, кг & 0,714 & 0,792 & 0,901 & 1,00 & - & - \\
\hline Середня фітомаса кори, кг & 0,750 & 0,810 & 0,931 & 0,997 & 1,00 & - \\
\hline Середня фітомаса крони, кг & 0,902 & 0,595 & 0,930 & 0,763 & 0,802 & 1,00 \\
\hline
\end{tabular}

Табл. 2. Показники регресійної статистики та дисперсного аналізу деревини Picea abies (L.) H. Karst. y Передкарпатському лісогосподарському окрузі / The indicators of regression statistics and disperse analysis of Picea abies (L.) H. Karst. wood in the Precarpathian forestry district

\begin{tabular}{|c|c|c|c|c|c|c|c|}
\hline \multicolumn{8}{|c|}{ Регресійна статистика } \\
\hline \multicolumn{2}{|c|}{ Множинний $R$} & $9,9 \times 10^{-1}$ & & & & & \\
\hline \multicolumn{2}{|c|}{ Коефіцієнт детермінації $R^{2}$} & $9,9 \times 10^{-1}$ & & & & & \\
\hline \multicolumn{2}{|c|}{ Нормований $R^{2}$} & $9,9 \times 10^{-1}$ & & & & & \\
\hline \multicolumn{2}{|c|}{ Стандартна помилка } & $1,6 \times 10^{-2}$ & & & & & \\
\hline \multicolumn{2}{|c|}{ Спостереження } & 41,0 & & & & & \\
\hline \multicolumn{8}{|c|}{ Дисперсійний аналіз } \\
\hline \multicolumn{2}{|c|}{ Показник } & $\begin{array}{c}d f(\text { кількість } \\
\text { ступенів волі) }\end{array}$ & $\begin{array}{c}S S \text { (сума квадратів } \\
\text { відхилень) }\end{array}$ & $\begin{array}{l}M S \text { (оцінка } \\
\text { дисперсії) }\end{array}$ & $F$ & значущість $F$ & \\
\hline \multicolumn{2}{|c|}{ Регресія } & 2,0 & 2,5 & 1,3 & 4947,0 & $1,2 \times 10^{-46}$ & \\
\hline \multicolumn{2}{|c|}{ Залишок } & 38,0 & $1,0 \times 10^{-2}$ & $2,6 \times 10^{-4}$ & & & \\
\hline \multicolumn{2}{|c|}{ Разом } & 40,0 & 2,5 & & & & \\
\hline \multicolumn{2}{|c|}{ Показники } & коефіцієнти & стандартна помилка & $t$-статистика & $P$-значення & нижне $95 \%$ & верхнє $95 \%$ \\
\hline$Y-$ перетин & $\ln 10(y)$ & $-1,8$ & $4,4 \times 10^{-2}$ & $-41,5$ & $2,8 \times 10^{-33}$ & $-1,9$ & $-1,7$ \\
\hline Мінлива & $x_{1}$ & 1,9 & $5,5 \times 10^{-2}$ & 35,0 & $1,5 \times 10^{-30}$ & 1,8 & 2,0 \\
\hline Мінлива & $x_{2}$ & 0,9 & $4,4 \times 10^{-2}$ & 22,5 & $1,5 \times 10^{-46}$ & 0,9 & 1,1 \\
\hline
\end{tabular}

Табл. 3. Показники регресійної статистики та дисперсного аналізу кори Picea abies (L.) H. Karst. у Передкарпатському лісогосподарському окрузі / The indicators of regression statistics and disperse analysis of the bark of Picea abies (L.) H. Karst. in the Precarpathian forestry district

\begin{tabular}{|c|c|c|c|c|c|c|c|}
\hline \multicolumn{8}{|c|}{ Регресійна статистика } \\
\hline \multicolumn{2}{|c|}{ Множинний $R$} & $9,9 \times 10^{-1}$ & & & & & \\
\hline \multicolumn{2}{|c|}{ Коефіцієнт детермінації $R^{2}$} & $9,9 \times 10^{-1}$ & & & & & \\
\hline \multicolumn{2}{|c|}{ Нормований $R^{2}$} & $9,9 \times 10^{-1}$ & & & & & \\
\hline \multicolumn{2}{|c|}{ Стандартна помилка } & $1,9 \times 10^{-2}$ & & & & & \\
\hline \multicolumn{2}{|c|}{ Спостереження } & 41,0 & & & & & \\
\hline \multicolumn{8}{|c|}{ Дисперсійний аналіз } \\
\hline \multicolumn{2}{|c|}{ Показник } & $\begin{array}{c}d f \text { (кількість } \\
\text { ступенів волі) }\end{array}$ & $\begin{array}{c}S S \text { (сума квадратів } \\
\text { відхилень) }\end{array}$ & $\begin{array}{l}M S \text { (оцінка } \\
\text { дисперсії) }\end{array}$ & $F$ & значущість $F$ & \\
\hline \multicolumn{2}{|c|}{ Регресія } & 2 & 1,8 & 0,9 & 2412,5 & $9,2 \times 10^{-41}$ & \\
\hline \multicolumn{2}{|c|}{ Залишок } & 38 & $1,4 \times 10^{-2}$ & $3,8 \times 10^{-4}$ & & & \\
\hline \multicolumn{2}{|c|}{ Разом } & 40 & 1,8 & & & & \\
\hline \multicolumn{2}{|c|}{ Показник } & Коефіцієнти & стандартна помилка & $t$-статистика & $P$-значення & нижнє $95 \%$ & верхнє $95 \%$ \\
\hline$Y$-перетин & $\ln 10(y)$ & $-2,3$ & $5,3 \times 10^{-2}$ & $-43,6$ & $4,6 \times 10^{-33}$ & $-2,4$ & $-2,2$ \\
\hline Мінлива & $x_{1}$ & 1,6 & $6,7 \times 10^{-2}$ & 23,6 & $2,8 \times 10^{-30}$ & 1,4 & 1,7 \\
\hline Мінлива & $x_{2}$ & 0,9 & $5,4 \times 10^{-2}$ & 16,6 & $5,1 \times 10^{-46}$ & 0,8 & 0,9 \\
\hline \multicolumn{4}{|c|}{$\begin{array}{l}\text { Аналогічним аналізом одержано рівняння для визна- } \\
\text { чення фітомаси кори і деревини в інших лісорослинних } \\
\text { округах Picea abies (L.) H. Karst.: } \\
\text { • у Гірськокарпатському лісогосподарському окрузі: }\end{array}$} & $\begin{array}{l}\text { - деревина: } \\
\text { - кора: } \\
\text { в окрузі Зак }\end{array}$ & $\begin{array}{l}y=1,5 \cdot 10^{-2,0} . \\
y=4,7 \cdot 10^{-3,0} . \\
\text { арпатських рівн }\end{array}$ & $\begin{array}{l}1,8 \cdot x_{2}^{1,1}, R^{2}=0,9 \\
, 5 \cdot x_{2}^{1,0}, R^{2}=0,9 \\
\text { і передгір'я: }\end{array}$ & $\begin{array}{l}(12) \\
\text { (13) }\end{array}$ \\
\hline
\end{tabular}




$$
\begin{array}{ll}
\text { - деревина: } & y=1,3 \cdot 10^{-2,0} \cdot x_{1}^{0,9} \cdot x_{2}^{2,0}, R^{2}=0,999 ; \\
\text { - кора: } & y=2,9 \cdot 10^{-3,0} \cdot x_{1}^{1,9} \cdot x_{2}^{0,7}, R^{2}=0,998 .
\end{array}
$$

Для визначення конверсійних коефіцієнтів застосовано рівняння 4 та отримано числові значення (табл. 4). Отримані емпіричні рівняння апроксимуються на 6683 \% 3 фактичними даними, тому їх можна використовувати в подальших дослідженнях.

Табл. 4. Числові значення конверсійних коефіцієнтів насаджень Picea abies (L.) H. Karst / Numerical values of conver-

\begin{tabular}{|c|c|c|c|}
\hline \multirow{2}{*}{$\begin{array}{c}\text { Фракція } \\
\text { фітомаси, кг }\end{array}$} & \multicolumn{2}{|c|}{ Значення коефіцієнтів } & \multirow{2}{*}{$\begin{array}{c}\text { Коефіцієнт } \\
\text { детермінації, } R^{2}\end{array}$} \\
\hline & $a$ & $b$ & \\
\hline \multicolumn{4}{|c|}{ Передкарпатського лісогосподарського округу } \\
\hline деревина & 0,39 & 0,02 & 0,701 \\
\hline кора & 0,07 & $-0,25$ & 0,721 \\
\hline крона & 42,6 & $-1,59$ & 0,765 \\
\hline \multicolumn{4}{|c|}{ Гірськокарпатського лісогосподарського округу } \\
\hline деревина & 0,29 & 0,02 & 0,667 \\
\hline кора & 0,06 & $-0,21$ & 0,665 \\
\hline крона & 82,2 & $-1,78$ & 0,833 \\
\hline \multicolumn{4}{|c|}{ Лісогосподарський округ Закарпатських рівнин і передгір'я } \\
\hline деревина & 0,30 & 0,01 & 0,657 \\
\hline кора & 0,04 & $-0,11$ & 0,664 \\
\hline крона & 8,03 & $-1,17$ & 0,777 \\
\hline
\end{tabular}
sion factors of Picea abies (L.) H. Karst plantations

За допомогою отриманих математичних залежностей за рівнянням (3) (див. табл. 4) та методиками G. Matthews i I. Я. Лієпи встановлено вуглецепоглинальну та киснетвірну здатність насаджень Picea abies (L.) H. Karst. у віці 70 років на площі 1 га. При цьому середній запас ялинових насаджень у Передкарпатському лісогосподарському окрузі становить $360 \mathrm{~m}^{3} /$ га, Гірськокарпатському - $470 \mathrm{~m}^{3} /$ га, окрузі Закарпатських рівнин і передгір'я - $500 \mathrm{~m}^{3} /$ га (рис. 2).

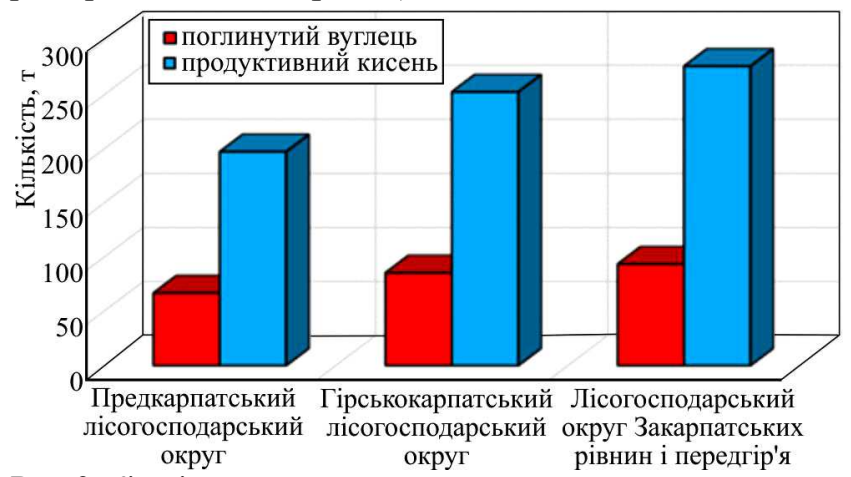

Рис. 2. Кількість поглинання вуглецю та продукування кисню ялиновими насадженнями у віці 70 років на площі 1 га / The quality of carbon repayment and production of acidic European spruce at the age of 70 in an area of 1 hectare

Отже, враховуючи всі показники встановлено, що у Передкарпатському лісогосподарському окрузі на площі 1 га Picea abies (L.) H. Karst. поглинає 67,1 т вуглецю та продукує 197,7 т кисню, а у Гірськокарпатському - 85,9 і 253,1 т відповідно, а в окрузі Закарпатських рівнин і передгір'я поглинає 93,9 т вуглецю та продукує 276,8 т кисню.

Згідно з показниками Державного лісового кадастру станом на 1 січня 2011 р. (Форма № 2), в Українських Карпатах запас деревини ялини становить 145,6 млн м³. Отже, загальна кількість поглинутого вуглецю та продукованого кисню Picea abies (L.) H. Karst. в Українських Карпатах становить 30,7 і 64,5 млн т відповідно.

За даними Головного управління статистики ми встановили, що основним джерелом забруднення $\mathrm{CO}_{2} \epsilon$ автотранспорт, середній обсяг викидів за період 20102020 рр. становить 18,6 млн т (рис. 3).

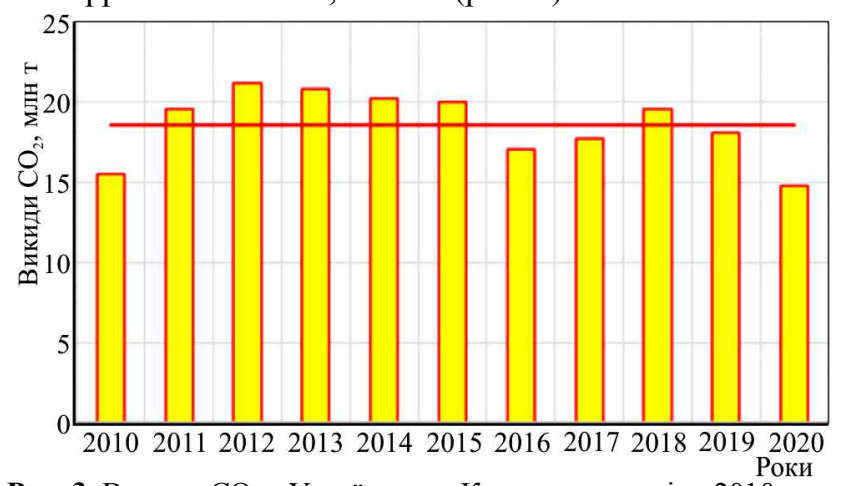

Рис. 3. Викиди $\mathrm{CO}_{2}$ в Українських Карпатах за період 20102020 pp. / $\mathrm{CO}_{2}$ emissions in the Ukrainian Carpathians for the period 2010-2020

Отже, ялинові насадження в повному обсязі знижують викиди $\mathrm{CO}_{2}$ в умовах Українських Карпат.

Обговорення результатів дослідження. Ялина європейська краще росте у Гірськокарпатському лісогосподарському окрузі, де висота $є$ вищою на 7 \% за висоту ялини у Передкарпатському округу і на $16 \%$ - від Закарпатського округу. Діаметр ялини у Гірськокарпатському лісогосподарському окрузі більший на $2 \%$, ніж у Передкарпатському і на $1 \%$, ніж у Закарпатському окрузі рівнин і передгір'я.

Picea abies (L.) H. Karst. у віці 70 років на площі 1 га у Передкарпатському лісогосподарському окрузі поглинає 67,1 т вуглецю та продукує 197,7 т кисню, у Гірськокарпатському - 85,9 і 253,1 т відповідно, а в окрузі Закарпатських рівнин і передгір'я поглинає 93,9 т вуглецю та продукує 276,8 т кисню. В Українських Карпатах загальний обсяг поглинутого вуглецю та продукованого кисню Picea abies (L.) H. Karst. становить 30,7 i 64,5 млн т відповідно.

Головним джерелом забруднення $\mathrm{CO}_{2} €$ автотранспорт, середній обсяг викидів за період 2010-2020 pp. становить 18,6 млн т. Ялинові насадження в повному обсязі знижують викиди $\mathrm{CO}_{2}$ в умовах Українських Карпат, що має вагоме кліматостабілізаційне значення.

\section{Висновок / Conclusions}

Під час математичного моделювання за допомогою кореляційного та регресійного аналізу отримано рівняння 3 високим коефіцієнтом детермінації, що дало змогу встановити вуглецепоглинальну та киснетвірну здатність ялини європейської (Picea abies (L.) H. Karst) в Українських Карпатах.

Встановлено, що ялина європейська найкраще розвивається в окрузі Закарпатських рівнин і передгір'я. 3'ясовано, що у віці 70 років на площі 1 га ялинові насадження найбільше поглинають вуглець - близько 117,6 т і продукують кисень - 346,6 т в окрузі Закарпатських рівнин і передгір'я.

Визначено, що загальний обсяг поглинутого вуглецю та продукованого кисню ялиновими насадженнями в Українських Карпатах становить 5,4 і 11,4 млн т відповідно.

Враховуючи обсяг викидів $\mathrm{CO}_{2}$ в навколишне природне середовище та обсяг поглинання вуглецю, можна стверджувати, що ялинові насадження відіграють важливе кліматостабілізаційне значення, зменшуючи обсяги викидів вуглекислого газу в повному обсязі. 


\section{References}

1. Gitarskiy, M. L. (Ed). (2017). Carbon flux from deadwood in the southern taiga forests of the Valdai Upland. Ekologiya, 6, 447453. https://doi.org/10.7868/S0367059717060063

2. Hrynyk, H. H., \& Zadorozhnyy, A. I. (2018). Models of dynamics of aboveground phytomass of European spruce trees depending on their taxonomic indicators in the predominant types of forest vegetation conditions of the Polonyn ridge of the Ukrainian Carpathians. Scientific Bulletin of UNFU, 28(2), 9-19. https://doi.org/10.15421/40280201

3. Ivanov, A. V. (Ed). (2018). Carbon emission from the surface of deadwood in the cedar forests of the Southern Primorye. Ekologiya, 4, 275-281. https://doi.org/10.7868/S0367059718040042

4. Kashpor, S. M., \& Strochinskiy, A. A. (2013). Forest evaluation Handbook. Kyiv: Vid. dim "Vinnichenko". [In Ukrainian].

5. Kucheryavyy, V. P. (2000). Ecology. Lviv: Svit. [In Ukrainian].

6. Lakyda, P. I. (2002). Phytomass of forests of Ukraine. Ternopil: Zbruch. [In Ukrainian].

7. Lakyda, P. I. (Ed). (2013). Standards for assessment of components of aboveground phytomass of forests of the main forest-forming species of Ukraine. Korsun-Shevchenkivskyy: FOP Havryshenko V. M. [In Ukrainian].

8. Liyepa, I. Ya. (1980). Dynamics of wood stocks: Forecasting and ecology. Riga: Zinatne. [In Latvia].

9. Lovynska, V. M. (2018). Aboveground phytomass of Pinus Sylvestris L. trunks in the stands of the northern steppe of Ukra- ine. Scientific Bulletin of NLTU of Ukraine, 28(8), 79-82. https://doi.org/10.31521/2313-092X/2018-3(99)-12

10. Lovynska, V. M. (2018). Local density of phytomass components of Scots pine trunk (Pinus sylvestris L.) of the Northern Steppe of Ukraine. Bulletin of Agrarian Sciences of the Black Sea Region, 3, 73-78. https://doi.org/10.15421/40280816

11. Matthews, G. (1993). The Carbon Contents of Trees. Forestry Commission, Tech. Paper 4. Edinburgh. [In Scotland].

12. Poluboyarinov, O. I. (1976). Density of wood. Moscow: Lesn. prom-st. [In Russian].

13. Sytnyk, S. A. (2019). Modeling of phytomass components of trunks of robinia stands of the Northern Steppe of Ukraine. Scientific Bulletin of NLTU of Ukraine, 29(3), 48-51. https://doi.org/10.15421/40290310

14. Sytnyk, S., Lovynska, V., \& Lakyda, I. (2017). Foliage biomass qualitative indices of selected forest forming tree species in Ukrainian Steppe. Folia Oecologica, 44(1), 38-45. https://doi.org/10.1515/foecol-2017-0005

15. Sytnyk, S., Lovynska, V., Lakyda, P., \& Maslikova, K. (2018). Basic density and crown parameters of forest forming species within Steppe zone in Ukraine. Folia Oecologica, 45(2), 38-45. https://doi.org/10.2478/foecol-2018-0009

16. Vysotska, N., Rumiantsev, M., \& Kobets, O. (2021). White poplar (Populus alba L.) stands in Ukraine: the current state, growth specificities and prospects of using for forest plantations. Folia Oecologica, 48(1), 63-72. https://doi.org/10.2478/foecol-2021$\underline{0008}$

V. V. Moroz' ${ }^{1}$ N. M. Stasyuk ${ }^{2}$, T. P. Fedonyuk ${ }^{1}$

${ }^{1}$ Polissya National University, Zhytomyr, Ukraine ${ }^{2}$ Institute of Agroecology and Environmental Management, NAAS Ukraine, Kyiv, Ukraine

\section{SOME PECULIARITIES OF GROWTH, DEVELOPMENT AND CLIMATE-STABILIZING SIGNIFICANCE OF SPRUCE STANDS OF THE UKRAINIAN CARPATHIANS}

The paper focuses on some peculiarities of growth, development, and climate-stabilising significance of spruce stands in the Ukrainian Carpathians. In the course of research correlation matrices were constructed using the Microsoft Excel data analysis package based on the obtained indicators of wood forest mensuration on temporary trial plots. Close correlations were established between such indicators as age, height, diameter and phytomass of individual wood fractions. Regression and disperse analysis were performed, and mathematical dependences were obtained, which established the development of European spruce (Picea abies (L.) H. Karst.) in height, diameter and age of the tree. Empirical equations show that European spruce grows best in the Mountain Carpathian Forest District. In this district, the height of spruce is $7 \%$ higher than in the Precarpathian district and $16 \%$ higher than in the Transcarpathian district. The study has also found that the diameter of spruce is larger in the Mountain Carpathian Forestry District than in the Pre-Carpathian by $2 \%$, and the Transcarpathian by $1 \%$ respectively. Spruce stands are determined to absorb the most carbon -93.9 tons, and produce oxygen -276.8 tons on the area of 1 hectare in the Transcarpathian plains and foothills. In the Mountain Carpathian Forestry District, Picea abies (L.) H. Karst absorbs 85.9 tons of carbon and produces 253.1 tons of oxygen, and in the Carpathian Forest District - 67.1 tons and 197.7 tons respectively. Carbon dioxide emissions into the environment in the Ukrainian Carpathians for years 2010-2020 were analyzed. During this period the average $\mathrm{CO}_{2}$ emissions amounted to 18.6 million tons. Spruce stands are revealed to completely reduce $\mathrm{CO}_{2}$ emissions in the environment of the Ukrainian Carpathians. To conclude, proposed mathematical equations will allow monitoring the amount of carbon sequestration and oxygen production by Picea abies (L.) H. Karst. in different forest vegetation districts of the Ukrainian Carpathians.

Keywords: carbon; oxygen; phytomass; equation; carbon dioxide. 